\title{
An Empirical Assessment of Demographic Factors, Organizational Ranks and Organizational Commitment
}

\author{
Adnan Iqbal \\ College of Business Administration, Prince Sultan University \\ P.O. Box 66833, Riyadh 11586, Kingdom of Saudi Arabia \\ Tel: 966-1-4508046_E-mail: dradnan_iqbal@yahoo.co.uk; aiqbal@fnm.psu.edu.sa
}

\begin{abstract}
This study investigated the relationship between demographic factors (age, tenure and level of education) and organizational commitment. The data was collected from the knitwear organizations in Lahore and Faisalabad, Pakistan. Five set of questionnaire per organization were distributed to assess the perceived employees' commitment through self reported Organizational Commitment Questionnaire (OCQ) and biographical factors form. The results of the data showed that length of service is significantly associated with organizational commitment, whereas, education level is negatively correlated with organizational commitment. Furthermore, no significant correlation was found between organizational commitment and age. The results of this study also showed that the managers and the supervisors are more committed than the workers. The findings suggested that top management might be able to increase the level of commitment in the workers by increasing employee satisfaction with compensation, policies, training, and working conditions. Furthermore, managers can increase organizational commitment by communicating that they value employees' contribution and that they care about employees' well being.
\end{abstract}

Keywords: Commitment, Job satisfaction, Organizational tenure, Organizational commitment questionnaire (OCQ), Pakistani Knitwear, Analysis of variance (ANOVA), Job category, Correlations

\section{Introduction}

Organizational commitment is the degree to which an employee identifies with the organization and wants to continue actively participating in it (Newstrom, 2007). Organizations, however, are complex and made up of number of divisions each with their own agendas and goals. Commitment can therefore be directed at specific aspects of a person's job such as department, the location, and trade unions (Mathewman, Rose \& Hetherington, 2009). Swailes (2002) suggested the four bases of organizational commitment. Table 1, presents the summary and contrast of the four bases of organizational commitment.

Organizational commitment has been extensively researched; however, the relationship between demographic factors and attitudinal commitment has not been fully explored (Mathieu \& Zajac, 1990). In this paper, the relationship between demographic factors (age, education and tenure) and attudinal commitment is exposed in the Pakistani Knitwear Industry.

Previous researchers (e.g. Schneider, Hall \& Nygren (1970)) demonstrated that when the goals of the organizations and the members of the organizations integrated or congruent, attitudinal commitment occurs. Therefore, attitudinal commitment represents a state in which an individual identifies with a particular organization and its goals, and maintains membership in order to facilitate these goals (Mowday, Porter \& Steers, 1982). Furthermore, organizational commitment has been identified as a useful measure of organizational effectiveness (Steers, 1977) and explaining the work-related behaviour of employees in organizations (Mowday et al., 1982). Therefore, Organizational commitment has emerged as a promising area of research within the study of Industrial/Organizational psychology in recent times (Salami, 2008)

\section{Literature Review}

Organizational commitment has been researched with two constructs for analysis. These are Behavioural Perspective and Attitudinal Perspective. 


\subsection{Behavioural perspective}

Early researchers (Alluto, Herbiniak \& Alonso, 1973; Angle \& Perry, 1983; Becker, 1960) have focussed on a behavioural definition of commitment. They explained organizational commitment as a binding of the individual to behavioural acts. Becker (1960) argued that an individual acts in a committed manner because previously extraneous situational factors have become agents of influence or 'investment' in the individual's present actions. This theory was later rejected by Ritzer \& Trice (1969) and Aranya \& Jacobson (1975). However, Angle \& Perry (1983) affirmed Becker's Behavioural Perspective. Alluto et al (1973) expanded the Becker's theory of 'side-bet' (See Note 1) and included the notion of the 'investment' in this theory. After the rejection of this theory, researchers focussed there attentions on the attitudinal commitment.

\subsection{Attitudinal perspective}

\subsubsection{Mowday, Porter and Steers (1982) Model}

Commitment (Attitudinal Commitment), to an organization involves three components: (a) a strong belief in and acceptance of organizational goals and values, (b) a willingness to exert considerable effort on behalf of the organization, and (c) a strong desire to maintain membership in the organization (Mowday et al, 1982). Research on organizational commitment has been examined primarily in relation to labour turnover (Ferris \& Aranya, 1983; Hom, Katerberg \& Hulin, 1979; Huselid \& Day, 1991; Mowday, Steers \& Porter, 1979; O'Reilly \& Caldwell, 1980; Wiener \& Vardi, 1980; Steers, 1977; Stumpf \& Hartman, 1984).

\subsubsection{Meyer and Allen (1997) Model}

Meyer and Allen (1997) view organizational commitment as a 'three component' concept. The three components in their model are 'Affective', 'Continuous', and 'Normative'. The affective commitment describes the emotional attachment an individual has with the organization, their identification with the goals and values of the organization and the level of their involvement (Zanagro, 2001). Affective commitment is taken as a construct closely related to identification (Bergami \& Bagozzi, 2000). Continuance commitment is based on the cost that an employee associates with leaving the organizations, such as reduction in pay, pension, benefits, or facilities (Herbiniak \& Alluto, 1972). Normative commitment is associated with employees' feelings of obligation to continue employment due to the work culture and other socially accepted norms (Weiner \& Gechman, 1977). The less common approach to viewing commitment is in terms of obligation. Of the three components least is known about the development of normative commitment (Meyer \& Allen, 1997).

\section{Organizational Commitment Empirical Review}

The majority of researchers have treated organizational commitment as a dependent variable in their studies (Morrow, 1983 in DeCotiis \& Summers, 1987). For instance, Steers (1977) examined the relationship between work related variables as antecedents of climate (group attitudes, organizational dependability, and personal impact) and organizational commitment. This study was carried out among 382 hospital employees, 119 scientists and engineers.

The relationship between organizational commitment and other outcomes has also been examined in developing countries. For instance, Ahmed \& Alvi (1987) surveyed 1116 employees in various organizations of Pakistan. Exchanged-base variables included wage, job, security, union affiliation, tenure and type of organization. They found that interested work, task identity, peer's friendliness, and authority turned out to be factors that had a significant positive influence on commitment. They also confirmed that any organization which fulfils its workers' psychological needs, along and provides a better working environment enhances their commitment.

Another study was carried out by Khaleque \& Rahman (1987) to measure overall job satisfaction of industrial workers in Bangladesh. This study was designed to 1) measure the overall job satisfaction of industrial workers; 2) determine the influence of some personal factors and job facets on the overall job satisfaction of the workers; and 3) evaluate the perceived importance of some facets on the overall job satisfaction of the workers. They found that some specific aspects of jobs, such as good relations with peers, convenient work scheduling, good working environment, and a job security had stronger influence on job satisfaction and commitment.

Demographic factors such as age, tenure, and education level have been associated with organizational commitment (Abdulla \& Shaw, 1999; Chughtai \& Zafar, 2006; Dodd-McCue \& Wright, 1996; Luthans, McCaul \& Dodd, 1985; Morrow, 1993; Salami, 2008); however, Mathieu \& Zajac (1990) and Weidmer (2006) in Salami (2008) found that demographic factors were not significant predictor of organizational commitment.

Viewing commitment as an affective or emotional attachment to an organization is the most common approach in the literature to studying commitment (Mowday et al, 1982). The present study was delimited to using primarily the attitudinal perspective of commitment. Present study is an inquiry into the attitude and perception which employees have towards commitment in Pakistani knitwear industry. 


\section{Purpose of the Study}

The main purpose of this study is to investigate the relationship between demographic factors and organizational commitment within the Pakistani knitwear industry. Pakistan knitwear industry was chosen as it is highly labour intensive and contributes $60 \%$ in the economy of Pakistan. Above all, the best suited to test these variables (Demographic and attitudinal commitment) in this study. Pakistan was mainly based on agrarian economy. Since its independence in 1947, Pakistan has been able to transform itself to a large extent, from a completely agrarian economy to a fairly developed techno-industrial base (United Nations Economic and Social Commission for Asia and the Pacific publications, 2002). However, The knitwear industry in Pakistan is fast losing its benefits in lower raw material, financial incentives and post WTO regime (Anonymous, 2006b); monetary, product mix, quota, technology and human resource issues (Noshab, 2006). Apart from the other issues labour situation is quite crucial and needs thorough attention.

Many organizations in Pakistan hold the traditional view that technical excellence is the primary key to achieve business successes. The relatively low emphasis on all other forms of employee training demonstrates an unwillingness to teach other part of the business (Saigol, 1998).An abundance pool of labour does not mean anything if it is not developed and trained to face the new challenges. Akhtar (2006) suggested that in going forward to implement the real vision, Pakistan should plan to raise its investment in infrastructure and human resources, as shortcomings in these areas are now hurting Pakistan's industrial and export competitiveness.

Other objective of this study is to explore the significance difference in perceptions of three Ranks/Job categories i.e. managers, supervisors, and workers for organizational commitment in the Pakistani knitwear industry. Furthermore, here are many justifications for this study:

1) The literature suggested a relationship between Personal/demographic and organizational commitment but with a corresponding lack of evidence. The relationships, between demographic factors and organizational commitment have not been adequately explored.

2) It was found that very limited research had been conducted that established relationship between demographic factors and organizational commitment in Pakistani context, and none of the research found was conducted in Pakistani knitwear context. So there is need to gain understanding about predicting factors for organizational commitment in the Pakistani knitwear sector.

So, there is need to gain understanding about predictors of organizational commitment among Pakistani workforce.

\section{Hypotheses}

In order to achieve the purpose of this study, the following hypotheses were tested:

\subsection{Demographic Factors:}

\subsubsection{Age}

Some researchers found a significant and positive relationship between age and employees' commitment. For instance, Mathieu \& Zajac (1990) found that age is significantly associated with organizational commitment. Sommer, Bae \& Luthans (1996) confirmed the previous finding and noted that the organizational commitment among Korean employees increases with age. Researchers suggest that older workers are likely to experience higher level of commitment (Abdulla \& Shaw, 1999). This finding may be due to the fact that older people at workplace lower their expectations to more realistic levels and adjust themselves better to their work situations (Newstrom, 2007). Therefore, the following hypothesis is proposed:

Hypothesis 1: Employee's attitudinal commitment is significantly and positively associated with demographic factor (age) in the Pakistani knitwear industry.

\subsubsection{Level of education}

Level of education is another demographic factor that has been related to organizational commitment. Steers (1977) found that level of education was negatively related to organizational commitment. Similarly, Mathieu \& Zajac's (1990) meta-analysis confirmed this relationship and found that the relationship was significantly stronger but negative for attitudinal commitment. Highly educated individual may have less commitment since they may have other opportunities of employment. So, it is assumed that:

Hypothesis 2: Employee's attitudinal commitment is significantly and negatively associated with demographic factor (education level) in the Pakistani knitwear industry.

\subsubsection{Organizational tenure (length of service)}

Commitment is usually stronger among long-term stay employees (Newstrom, 2007). Meyer, Herscovitch \& Topolnytsky (2002) found a significant and positive relationship between organizational commitment and 
organizational tenure. They further suggest the possibility that the longer a person works in an organization and the older they become their feelings of responsibility for outcomes relevant to them also increases. Salami (2008) also identified a positive and strong relationship between organizational tenure and organizational commitment. Therefore, the following hypothesis is proposed:

Hypothesis 3: Employee's attitudinal commitment is significantly and positively associated with demographic factor (Tenure) in the Pakistani knitwear industry.

Addition to this, past research (for instance, Bridges and Harrison, 2003) indicates that employee perceptions are an important factor for predicting organizational commitment. Perception varies a lot from time to time, place to place and person to person. Therefore, following hypothesis is proposed to study employees' perceptions.

Hypothesis 4: There is a significant difference in perception of employees' categories for organizational commitment in the Pakistani knitwear industry.

\section{Method}

The present study is a relationship based research in that it attempts to establish a correlation between personal factors (Age, tenure and education level) and organizational commitment in the Pakistani knitwear industry. This study was carried out in Pakistani knitwear units located in Lahore and Faisalabad. The study was conducted in the form of self-administered surveys (questionnaires). Research design is the structure of research that links the empirical data to be collected to the study's initial research questions and ultimately to its conclusions (Yin, 1994). A demographic questionnaire was administered and incorporated the following items, Age, job category (manager, supervisor and worker), length of service and education level. In order to explore the significant difference among the perception of employees (Hypothesis 4), only job category item was selected for this study.

\subsection{Sample}

The population of knitwear units for this study was obtained from the 'Member directory published by Pakistan Hosiery Manufacturing Association' (Anonymous, 2006a). A sample consisted of about 100 knitwear units with the help of systematic random sampling (SRS) from the population of 432 organizations in Lahore (235) and Faisalabad (197). After a couple of reminders and visits, 415 questionnaires from 85 organizations were returned. Of the 415 questionnaires 353 were found to be valid, which is a useable response rate of $83 \%$. Of the 353 respondents $117(33 \%)$ managers, $142(40 \%)$ supervisors and 94(27\%) workers, this shows a good representation of staff. Furthermore, $60 \%$ respondents were below 30 years. $26 \%$ of supervisors were under the age of 30 . But with only $3.2 \%$ falling in the $50-59$, and 60 and above years of age categories, above 50\% employees sample had School certificate (O-levels) qualification. Finally, $87 \%$ workers have less than ten years working experience.

The knitwear sector in Pakistan is highly compact and simple in terms of structure and location and in most of the organizations general managers and higher authority have direct interaction with supervisors and workers. Participation was voluntary and confidentiality was guaranteed. Questionnaires (Organizational commitment Questionnaire and Demographic questionnaire) were contextualised in the Pakistani environment and translated in Urdu language (National language) and then in English. The Urdu translation was undertaken by an eminent faculty member of Punjab University Lahore, Pakistan.

\subsection{Measures}

There were two parts of questionnaire:

\subsubsection{Basic Demographics}

A demographic questionnaire was administered and incorporated the following items, age, job category (manager, supervisor and worker), length of service, and education level. Age was measured in five categories, from 1 (less than 29 years) to 5 (60 and above). Education level was coded in eight categories, $0=$ 'Others', $1=$ 'Primary', to $8=$ 'University degree'.

\subsubsection{Organizational Commitment}

Mowday et al.'s (1982) Organizational Commitment Questionnaire (OCQ) is used to measure employees' commitment to their organizations. The internal consistency reliability (Cronbach's alpha) for OCQ in this study was 0.863 . This instrument measures attitudinal commitment, and consists of 15 items (six statements were negative). Examples of these items are: "I am willing to put in a great deal of effort beyond that normally expected in order to help this organization to be successful", "I talk up this organization to my friends as a great organization to work for", "I am extremely glad I chose this organization to work for over others I was considering at the time I joined". A five point scale ranging from 1 (strongly disagree) to 5 (strongly agree) was employed. Scores on the 15 items were averaged to yield a summary, score reflecting organizational commitment. 


\section{Results}

\subsection{Descriptive Analyses}

Section I of the survey yielded demographic information on the sample being studied. Of the $\mathrm{N}=353$ respondents $117(33 \%)$ managers, 142 (40\%) supervisors and 94(27\%) workers (see Table 2), which shows a good representation of staff.

According to Table 3, respondent were quite evenly spread across the age groups. $60 \%$ respondents were below 30 years. $26 \%$ of supervisors were under the age of 30 . But with only $3.2 \%$ falling in the $50-59$, and $60+$ years age categories. The age ranges from 18 to 65 years.

Table 4 shows the data on education level and job category. $26 \%$ of the respondents had university degrees and of that $26 \%, 21 \%$ were managers. Above 50\% employees sample have college (O-levels) qualification.

Table 4 shows the data of length of service of respondents. $66 \%$ employees have less than 5 year tenure in the organizations. In general $87 \%$ workers have less than ten years working experience.

\subsection{Correlations}

Results on Table 6 show significant positive correlation between organizational commitment and length of service $(\mathrm{r}=.16, \mathrm{p}<0.01)$, hence, Hypothesis 3 is supported. Result also reveals that a negative correlation between education level and organizational commitment $(\mathrm{r}=-.10, \mathrm{p}<0.05)$, Hypothesis 2 is supported. No significant correlation found between organizational commitment and age, therefore Hypothesis 1 is not supported.

\subsection{Analysis of variance (ANOVA)}

One way ANOVA was conducted to determine any significant difference among the three groups of employees' job levels in their perceptions of organizational climate. The Table 7 shows the results for organizational commitment.

Findings from the analysis of variance tests, as shown in Table 7, revealed that there were significant differences among the three groups regarding employees commitment on the statement 'proud to tell others about their organization' (f ( 2 , $350)=3.072, p=0.048)$, 'Little change in their circumstances' $(\mathrm{f}(2,350)=12.931, \mathrm{p}=0.000)$ and 'not much gain from this organization' $(\mathrm{f}(2,350)=6.798, \mathrm{p}=0.001)$.

A significant probability for ANOVA indicates that at least one pair of means was different. Thus, Hypothesis 4 is supported. To determine which pairs of means were different, the Tukey (HSD) post-Hoc test was conducted.

A Tukey (HSD) post hoc test (See Table 8) was used to determine the significant differences in groups regarding the organizational commitment in terms of proud to tell others about their organization. The results showed that there was significant difference between the mean of supervisors $(\mathrm{M}=4.34)$ and the mean of workers $(\mathrm{M}=4.01)$. However, the mean of managers $(\mathrm{M}=4.17)$ did not show statistical difference either with supervisors or workers. In this case, supervisor had higher mean than managers and workers.

Results of Tukey (HSD) post hoc for little change in their circumstance, indicated that there were significant differences between the mean of supervisors $(M=3.43)$ and the mean of workers $(M=2.84)$ and between the mean of workers and the mean of managers $(\mathrm{M}=3.61)$. In both instances, managers had a higher mean, than, that of supervisors and workers. However, there was no statistically difference in the mean of managers and supervisors.

For the statement 'no much gain from this organization' the results of Tukey (HSD) showed that there were significant differences between the mean of managers $(M=0.025)$ and the mean of supervisors $(M=2.44)$ as well as the mean of workers $(M=2.23)$ and the mean of managers $(M=2.85)$. In both instances managers had a higher means than supervisors and workers. There was no statistical significance between supervisors and workers on 'no much gain from this organization'.

\section{Discussion}

The results from this study indicated that the some of the demographic factors such as length of service is significantly and positively associated with organizational commitment in the Pakistani knitwear sector. This finding is consistent with the finding of number of previous researchers who found length of service is correlated with organizational commitment (Mathieu and Zajac, 1990; Meyer et al., 2002; Newstrom, 2007; Salami, 2008; Steers, 1977). They further suggest the possibility that the longer a person works in an organization and the older they become their feelings of responsibility for outcomes relevant to them also increases. This argument was further attested by Newstrom (2007). He noted that the organizationally committed employees, in general, will usually have good attendance records, demonstrate a willing adherence to company policies, and have lower turnover rates.

This study has also shown that there is a significant negative relationship between the educational level and the organizational commitment; it confirms the previous studies (Glisson \& Durick, 1988; Mathieu \& Zajac, 1990; Mowday et. al., 1982). This finding may be due to the fact that the highly educated people may have developed higher 
expectation from their serving organizations that it may not be able to adequately meet (Mowday et. al., 1982). On the other hand, this finding also envisages that as employees acquire more education, management's view to the value of their educational achievement decreases. High levels of educational achievements are sometimes viewed as unnecessary for many positions in a knitwear industry.

No significant correlation was found between organizational commitment and demographic factor (age), this finding is in line with the work previous researchers (Chaughtai \& Zafar, 2006; Weidmer, 2006 in Salami, 2008). There are many explanations for this finding. One of the most significant problems facing the Pakistani knitwear industry is that of employee turnover, the sense of being an integral part of the organization.

During the data collection for this study, the researcher observed some very crucial issues in the knitwear industry particularly and textile mills in general are working conditions or environment. Working conditions were poor, below acceptable working standards. Workers were exposed to considerable health hazards, from air borne fibres, air-conditioning, floor conditions (open drains, chemicals/water and damaged floors) and excessive materials handling to and from the machines. The findings reveal that the concern given by the management to work risks is non-existent. Industrial safety and health management practices are non-existent. Although the management claimed that there were no significant work-related accidents, one wonders if the reasons for high absenteeism and labour turnover is ever analysed to determine the causes. Top management and policy makers should revisit their policies and should bring new drastic and dramatic reforms to avoid any further alarming situation in the Pakistani knitwear industry.

One of the objectives of this study was to examine the perception of employees towards organizational commitment. In order to explore the differences in perception among the three job levels, one-way analysis of variance (ANOVA) followed by Tukey's honestly significant difference (HSD) test was used.

Results indicate that (see Table 8) on the statement 'proud to tell others about my organizations', workers show less commitment than managers and supervisors. There could be several explanations for this finding. First, the knitwear industry is not a pay master and most of the workers hired are on a contractual basis. They are paid on the basis of their production (per unit rate). On the other hand, supervisors and managers are inducted as permanent employees. Secondly, strict hierarchical structures, unrealistic production targets, verbal abuse and in some cases assaults by supervisors, as well as poor working conditions, lack of rest times and lack of growth are a few of the problems faced at the work place. Thirdly, there seems to be no evidence of direct consultation with employees regarding skills/knowledge gaps. These employers are likely to provide only limited on-the-job training and in most of organizations it was observed that training was one of the lowest priorities of the employers. As the provision of inadequate equipment, lack of training and adverse working conditions has been shown to affect employee commitment and intention to stay with the organization (McGuire and McLaren, 2009). The main reason behind poor training procedures, as observed in most of the knitwear units are primarily, the unaffordable cost of releasing operational staff for further trainings.

During data collection, this issue was also discussed with top-management when it was asked from one of senior manager, he explained that

Top-management has no trust in their employees they feel that if we have sent any worker for further training then that worker would not come back or would ask for higher salaries on their return.

On the statement 'little change in my circumstance', workers had difference of opinion with supervisors and managers. Managers and supervisors believe changes in their circumstances. Same with other statement 'No much gain from this organization'. Workers and supervisors have different stances than that of managers. Most of the managers learn all the relevant skills in their jobs. Unfortunately, local institutions do not impart the right skills to their graduates. Most of educational institutes do not have any interaction with industry which results in most managers learning both technical and managerial skills on the job. This is also reflected in managers' responses.

\section{Managerial Implications}

In general, leadership (top management and senior managers) can be regarded as the driving force for organizations on the path of productivity. They can give the assurance of and commit themselves to modelling the desired behaviours combined with the values that need to be institutionalised. Managers can increase organizational commitment by communicating that they value employees' contribution and that they care about employees' well being (Stinglhamber \& Vandenberghe, 2003). The findings from this study will help senior managers to identify those employee related issues that can slow productivity in the workplace. The Pakistani knitwear industry is highly labour intensive; therefore, prescribed findings of this study will directly impact on the increasing commitment and training strategy of the knitwear units. Furthermore, top management in the knitwear sector who wish to increase the employees' commitment should concentrate on a training structure, formal and informal communication and consideration with their followers. Workers could be interviewed (formal and informal) to determine their perceptions of the management's ability to address these issues. It is also important to foster good communication with employees and establish a comfortable rapport, 
encourage the employees to offer input and consider carefully what is said (Fox \& Dale, 2008). However, debate is ongoing as how to motivate contractual/temporary employees, which are essential part of knitwear industry.

\section{Summary and Conclusion}

Firstly, this study is cross-sectional and therefore takes the one time views of respondents about organizational commitment in the Pakistani knitwear industry. It is suggested that future research should be undertaken on a longitudinal basis. Secondly, trends in knitwear sector exhibit an association of with political condition and global crisis. The knitwear sector crisis was associated with political instability for many years and growing unpopularity of the previous regimes. For example, the second cotton crisis of the 2000s and the accompanying economic decline have seen the dismissal of two governments and growing public disenchantment with government in general. However, there is a hope that change in regime from military to democratic government might bring positive impact on knitwear sector and will impact employees' commitment in general. It is also suggested that government should play a positive role in industry survival. The industry needs low cost abundant energy and an efficient infrastructure with clean water and good roads to remain viable. These are the basics which any government should provide to an industry that accounts for $60 \%$ of all the exports of the country (Anonymous, 2007). Thirdly, limitation can be western-based theories of organizational commitment applied in this study. However, research instruments were adapted and contextualised to acknowledge this limitation. Finally, this study was limited to the knitwear industry in Pakistan and it may be difficult to generalize the results to other sectors of Pakistan.

In conclusion, results of this study identified the notion that, in the sampled group, organizational commitment does vary significantly among the three groups of employees. The significant relationships found in the data are that the managers and the supervisors are more committed than the workers. The findings also suggested that top management might be able to increase the level of commitment in the organization by increasing employee satisfaction with compensation, policies, and working conditions. One way of addressing this could be by increasing the interactions with workers in their workplaces and increasing guided discussions on topics such as safety \& security, trainings, participative management programmes, team work and other work related issues

\section{References}

Abdulla, M. H. A., \& Shaw, J. D. (1999). Personal Factors and organizational commitment: Main and interactive effects in the United Arab. Journal of Managerial Issues, 11, 77-93.

Ahmed, S. W., \& Alvi, S. A. (1987). Assessing Organizational Commitment in a developing country: Pakistan, A case Study. Human Relations, 40(5), 267-280.

Akhtar, S. (2006). Economic Transformation of Pakistan, Speech delivered at US Chamber of Commerce. Washington DC, [Online] Available: http://www.bis.org/review/r060705c.pdf (December 5, 2009).

Alluto, J., Herbiniak, L., \& Alonso, R. (1973). On operationalzing the concept of commitment. Social Forces, 51(4), $448-454$

Angle, L., \& Perry, L. (1983). Organizational Commitment: Individual and Organizational Influence. Work and Occupation, 10(2), 123-146.

Anonymous. (2006a). Pakistan Hosiery Manufacturing Association Member Directory. Lahore: Published by PHMA

Anonymous. (2006b). Trade Policy Speech by Minister of Commerce, Government of Pakistan: [Online] Available: http://www.commerce.gov.pk/Tradepolicy-1.asp (October 23, 2009)

Anonymous. (2007). Apparel and Knitwear sectors need a new vision in 2007. Pakistan Textile Journal, [Online] Available:

http://ptj.com.pk/newsite/editorial/Issue_03_2007/apparel-and-knitwear-sectors-need-a-new-vision-in-2007-2.html (October 22, 2009).

Aranya, N., \& Jacobson, D. (1975). An empirical study of theories of organizational and occupational commitment. Journal of Social Psychology, 97, 15-22.

Becker, H. S. (1960). Notes on the concepts of commitment. American Journal of Sociology, 66, 32-40.

Bergami, M., \& Bagozzi, R. P. (2000). Self-categorization, affective commitment and group self-esteem as distinct aspects of social identity in the organization. British Journal of Social Psychology, 39, 555-577.

Bridges, S., \& Harrison, K. (2003). Employee perceptions of stakeholder focus and commitment to the organization, Journal of Managerial Issues, 15, 498-509.

Chughtai, A., \& Zafar, S. (2006). Antecedents and Consequences of Organizational Commitment among Pakistani University Teachers. Applied H.R.M. Research, 11, 39-64. 
DeCotiis, A., \& Summers , P. (1987). A path-analysis of a model of the antecedents and consequences of organizational commitment. Human Relations, 40(7), 445-470.

Dodd-McCue, D., \& Wright, B. (1996). Men, women and attitudinal commitment: The effects of workplace experiences and socialization. Human Relations, 49, 1065-1089.

Ferris, K., \& Aranya, N., (1983). A comparison of two organizational commitment scales. Personnel Psychology, 36, $87-98$

Fox, L. M., \& Dale, K. (2008). Leadership styles and Organizational commitment: Mediating effect of role stress. Journal of Managerial Issues, 20(1), 109-130.

Glisson, C. A., \& Durick, M. (1988). Predictors of job satisfaction and organizational commitment in human service organizations. Administrative Science Quarterly, 33, 61-81.

Herbiniak, L. G., \& Alluto, J. A. (1972). Personal and role related factors in the development of organizational commitment. Administrative Science Quarterly, 17(4), 555-573.

Hom, P., Katerberg, R., \& Hulin, C. (1979). Comparative examination of three approaches to the prediction of turnover. Journal of Applied Psychology, 64(1), 280-290.

Huselid, M., \& Day, N. (1991). Organizational commitment, job involvement, and turnover: A substantive and methodological analysis. Journal of Applied Psychology, 76(3), 380-391.

Khaleque, A., \& Rahman, A. (1987). Perceived importance of Job Facets and overall Job satisfaction of industrial workers. Human Relations, 40(7), 401-416.

Luthans, F., McCaul, H. S., \& Dodd, N. G. (1985). Organizational commitment: a comparison of American, Japanese, and Korean employees. Academy of Management Journal, 28(2), 213-19.

Mathewman, L., Rose, A., \& Hetherington, A. (2009). Work Psychology. New York: Oxford University Press

Mathieu, J., \& Zajac, D. (1990). A review and meta-analysis of the antecedents, correlates, and consequences of organizational commitment. Psychological Bulletin, 108(2), 171-194.

McGuire, D., \& McLaren, L. (2009). The impact of physical environment on employee commitment in call centers; The mediating role of employee well-being. Team Performance Management, 15(1/2), 35.

Meyer J. P., \& Allen N J. (1997). Commitment in the workplace: Theory, Research and Application. California: Sage Publications.

Meyer, J., Herscovitch, S., \& Topolnytsky, L. (2002). Affective, Continuance, and Normative Commitment to the Organization: A Meta-analysis of Antecedents, Correlates, and Consequences. Journal of Vocational Behaviour, 61, 20-52.

Morrow, P. (1993). The theory and measurement of work commitment. Greenwich: CT JAL.

Mowday, R. T., Porter, L. W., \& Steers, R. M. (1982). Employee-organizational linkages: The Psychology of commitment, absenteeism, and turnover. New York: Academic Press.

Mowday, R.T., Steers, R. M., \& Porter, L. W. (1979). The measurement of organizational commitment. Journal of Vocational Behaviour, 14, 224-247.

Newstrom, J. W. (2007). Organizational Behaviour-Human Behaviour at work (12 ${ }^{\text {th }}$ ed). New York: McGraw Hill International Edition.

Noshab, F. (2006). Globalization, WTO and Pakistan. The Muslim World, 96(2), 341-2.

O'Reilly, C., \& Caldwell, D. (1980). The impact of intrinsic and extrinsic factors on subsequent satisfaction and commitment. Journal of Applied Psychology, 65(3), 559-565.

Ritzer, G., \& Trice, H. M. (1969). An empirical study of Howard Becker's Side-bet theory. Sociological Forces, 47(4): 475-479.

Saigol, T. S. (1998). Country perspective: Pakistan: The changing Textile face of Asia, Annual conference Report. International textile Manufacturers Federation.

Salami, S. O. (2008). Demographic and psychological factors predicting organizational commitment among. industrial workers. Anthropologist, 10, 31-38.

Schneider, B., Hall, D. T., \& Nygren, H. T. (1970). Personal factors in organization identification. Administrative Science Quarterly, 15, 176-189.

Sommer, S., Bae, M., \& Luthans, F. (1996). Organizational Commitment across Cultures: The Impact of Antecedents on Korean Employees. Human Relations, 49, 977-993. 
Steers, R. M. (1977). Antecedents and outcomes of organizational commitment. Administrative Science Quarterly, 22, $46-56$.

Stinglhamber, F., \& Vandenberghe, C. (2003). Organizations and supervisors as sources of support and targets of commitment. Journal of Organizational Behaviour, 24(1), 251-270.

Stumpf, S., \& Hartman, K. (1984). Individual exploration to organizational commitment or withdrawal. Academy of Management Journal, 27(2), 308-329

Swailes, S. (2002). Organizational commitment: a critique of the construct and measures. International Journal of Management Review, 4(2), 155-178

United Nations Economic and Social Commission for Asia and The Pacific publications: Pakistan: A country Profile, [Online] Available: http://www.unescap.org/tid/publication/part_two2223_pak.pdf (October 15, 2009).

Weiner, Y., \& Gechman, A. S. (1977). Commitment: A behavioural approach to job involvement. Journal of Vocational Behaviour, 10, 47-52.

Weiner, Y., \& Vardi, Y. (1980). Relationships between job, organization, and career commitments and work outcomes-an integrative approach. Organizational Behaviour and Human Performance, 26, 81-96.

Yin, K. (1994). Case Study Research: Design and Methods. Newbury Park, CA: Sage Publications.

Zanagro, G. A. (2001). Organizational Commitment: A concept analysis. Nursing forum, 36(2), 1-14

\section{Note}

Note 1. Side-bets are any investments of value made by both parties, which are not related to the job but serve to ensure continued organizational membership by the individual. As Becker (1960) said: "Commitments come into being when a person, by making a side-bet, links extraneous interests with a consistent line of activity."

Table 1. Four bases of Organizational commitment

Bases of organizational commitment

Originators/ Developers

\begin{tabular}{|c|c|}
\hline $\begin{array}{l}\text { Attitudinal or Affective commitment (Based } \\
\text { upon acceptance of and belief in the goals of } \\
\text { organization or group }\end{array}$ & $\begin{array}{l}\text { Etizioni (1961): Moral Commitment } \\
\text { Kanter (1968): Cohesion commitment } \\
\text { Mowday et. al (1982) } \\
\text { O'Reily and Chatman (1986): Internalisation }\end{array}$ \\
\hline $\begin{array}{l}\text { Continuance Commitment (Based upon } \\
\text { socioeconomic factors) }\end{array}$ & $\begin{array}{l}\text { Becker(1960): Side-bets Theory } \\
\text { Kanter (1968): continuance Commitment } \\
\text { Meyer and Allen(1984) } \\
\text { Mowday et. al (1982) } \\
\text { O'Reily and Chatman (1986): Compliance }\end{array}$ \\
\hline $\begin{array}{l}\text { Normative Commitment } \\
\text { (Based upon feelings of loyalty and } \\
\text { obligation) }\end{array}$ & $\begin{array}{l}\text { Allen and Meyer (1990) } \\
\text { Kanter(1968): Control commitment } \\
\text { O'Reily and Chatman (1986): Identification }\end{array}$ \\
\hline $\begin{array}{l}\text { Behavioural Commitment (Based upon } \\
\text { binding behaviour) }\end{array}$ & Salancik $(1977,1982)$ \\
\hline
\end{tabular}

Source: Swailes, S. (2002). Organizational commitment: a critique of the construct and measures 
Table 2. Respondent Job Category

\begin{tabular}{lrr}
\hline Job Category & Frequency & \multicolumn{2}{c}{ Valid Percent } \\
\hline & & \\
Manager & 117 & 33.1 \\
Supervisor & 142 & 40.2 \\
Worker & 94 & 26.6 \\
& & 100.0 \\
\hline Total & 353 & \\
\hline
\end{tabular}

Table 3. Age and Job Category

\begin{tabular}{llrrrr}
\hline & \multicolumn{2}{c}{ Respondent job category } & \multicolumn{2}{c}{ Total } \\
& & Manager & Supervisor & Worker & \% \\
\hline \multirow{2}{*}{ Age } & 11.4 & 25.9 & 22.5 & 59.8 \\
& $30-39$ & 14.0 & 11.4 & 3.4 & 28.8 \\
& $40-49$ & 5.4 & 2.6 & .3 & 8.3 \\
& $50-59$ & 1.4 & .3 & .6 & 2.3 \\
& $60+$ & .9 & & & .9 \\
\hline & Total \% & 33.0 & 40.2 & 26.8 & 100.0 \\
\hline
\end{tabular}

Table 4. Education Level and Job Category

\begin{tabular}{llllll}
\hline & & \multicolumn{2}{c}{ Respondent job category } & \multicolumn{2}{c}{ Total } \\
& & Manager & Supervisor & Worker & \% \\
\hline $\begin{array}{l}\text { Education } \\
\text { level }\end{array}$ & Other & & 0.3 & 1.4 & 1.7 \\
& & & & \\
& University & 20.4 & 5.4 & 0.0 & 25.8 \\
& Diploma & 3.4 & 2.5 & 0.0 & 5.9 \\
& Graduate & 5.1 & 11.3 & 2.0 & 18.4 \\
& College & 2.3 & 4.8 & .3 & 7.4 \\
& H.Sc (O-levels) & 2.0 & 13.0 & 9.6 & 24.6 \\
& Middle School & 0.0 & 1.7 & 4.5 & 6.2 \\
& Primary school & 0.0 & 1.1 & 8.8 & 9.9 \\
\hline & Total \% & 33.1 & 40.2 & 26.6 & 100.0 \\
\hline
\end{tabular}


Table 5. Length of Service and Job Category

\begin{tabular}{|c|c|c|c|c|c|}
\hline & & \multicolumn{3}{|c|}{ Respondent job category } & \multirow{2}{*}{$\begin{array}{c}\text { Total } \\
\%\end{array}$} \\
\hline & & Manager & Supervisor & Worker & \\
\hline \multirow{12}{*}{$\begin{array}{l}\text { Length of } \\
\text { service }\end{array}$} & $<=5$ & 16.5 & 27.6 & 21.7 & 65.8 \\
\hline & $6-10$ & 10.3 & 8.0 & 3.7 & 21.9 \\
\hline & $11-15$ & 4.3 & 3.1 & .9 & 8.3 \\
\hline & $16-20$ & 1.1 & 1.1 & & 2.3 \\
\hline & & & & - & \\
\hline & $21-25$ & .6 & .3 & & .9 \\
\hline & & & & - & \\
\hline & $26-30$ & .6 & & & .6 \\
\hline & & & - & - & \\
\hline & $31+$ & & & .3 & .3 \\
\hline & & - & - & & \\
\hline & Total $\%$ & 33.3 & 40.2 & 26.5 & 100.0 \\
\hline
\end{tabular}

Table 6. Correlations among All Study Variables

\begin{tabular}{clcccc}
\hline $\begin{array}{c}\text { Sr. } \\
\text { No. }\end{array}$ & $\begin{array}{c}\text { Attitudinal } \\
\text { Commitment }\end{array}$ & $\begin{array}{c}\text { Age of } \\
\text { Respondent }\end{array}$ & $\begin{array}{c}\text { Length of } \\
\text { service }\end{array}$ & $\begin{array}{c}\text { Education } \\
\text { level }\end{array}$ \\
\hline $\mathbf{1}$ & Attitudinal Commitment & 1.00 & & & \\
$\mathbf{2}$ & Age of Respondent & .08 & 1.00 & 1.00 \\
$\mathbf{3}$ & Length of service & $.16(* *)$ & $.70(* *)$ & $-.08^{*}$ & 1.00 \\
$\mathbf{4}$ & Education level & $-.10^{*}$ & -.06 & & \\
\hline
\end{tabular}

* Correlation is significant at 0.05 level

** Correlation is significant at 0.01 level

Table 7. Analysis of Variance of Employees' Commitment

\begin{tabular}{|c|c|c|c|c|c|}
\hline Employees' Commitment & & Mean & & $\mathbf{F}$ & Sig. \\
\hline & ${ }^{a} M$ & $S$ & $W$ & & \\
\hline $\begin{array}{l}\text { Proud to tell others about my } \\
\text { organization }\end{array}$ & 4.17 & 4.34 & 4.01 & 3.07 & $.04 *$ \\
\hline $\begin{array}{l}\text { little change in my } \\
\text { circumstances }\end{array}$ & 3.61 & 3.43 & 2.84 & 12.93 & $.00 * *$ \\
\hline $\begin{array}{l}\text { No much gain from this } \\
\text { organization }\end{array}$ & 2.85 & 2.44 & 2.23 & 6.80 & $.00 * *$ \\
\hline
\end{tabular}

* indicates that the mean difference is statistically significant at 0.05 level or lower.

** indicates that the mean difference is statistically significant at 0.01 level or lower

${ }^{\mathrm{a}} \mathrm{M}=$ Manager $\mathrm{S}=$ Supervisor $\mathrm{W}=$ Worker 
Table 8. Post Hoc (Tukey-HSD)

\begin{tabular}{|c|c|c|c|c|}
\hline Employees commitment & Mean & $\begin{array}{l}\text { Job } \\
\text { Category }\end{array}$ & $\mathbf{F}$ & Sig. \\
\hline Proud to tell others about my & ${ }^{\mathrm{a}} \mathrm{M}=4.17$ & $\mathrm{M} / \mathrm{S}$ & 3.07 & 0.38 \\
\hline \multirow[t]{2}{*}{ organization } & $\mathrm{S}=4.34$ & $\mathrm{~S} / \mathrm{W}$ & & $0.04 *$ \\
\hline & $\mathrm{W}=4.01$ & $\mathrm{M} / \mathrm{W}$ & & 0.48 \\
\hline \multirow[t]{3}{*}{${ }^{1}$ Little change in my circumstances } & $\mathrm{M}=3.61$ & $\mathrm{M} / \mathrm{S}$ & 12.93 & 0.42 \\
\hline & $\mathrm{S}=3.43$ & $\mathrm{~S} / \mathrm{W}$ & & $0.00^{*}$ \\
\hline & $\mathrm{W}=2.84$ & $\mathrm{M} / \mathrm{W}$ & & $0.00^{*}$ \\
\hline \multirow[t]{3}{*}{${ }^{1}$ No much gain from this organization } & $\mathrm{M}=2.85$ & $\mathrm{M} / \mathrm{S}$ & 6.80 & $0.03 *$ \\
\hline & $\mathrm{S}=2.44$ & $\mathrm{~S} / \mathrm{W}$ & & 0.42 \\
\hline & $\mathrm{W}=2.23$ & $\mathrm{M} / \mathrm{W}$ & & $0.00 *$ \\
\hline
\end{tabular}

* indicates that the mean difference is statistically significant at 0.05 level or lower.

${ }^{a} \mathrm{M}=$ Manager $\mathrm{S}=$ Supervisor $\mathrm{W}=$ Worker

$1=$ negative statements and reversed scores. 